\title{
Bifidogenic Effects of the Oral Administration of Fly Maggot Extract on Organic Acid, Cecal Microorganisms, Thymus and Spleen Weights, and Blood Lipids in Rats
}

\author{
Byung-Sung Park ${ }^{1}$ and Sang-Oh Park ${ }^{2 *}$ \\ ${ }^{1}$ Devision of Applied Animal Science, Kangwon National University, Chuncheon 200-701, Korea \\ ${ }^{2}$ Institute of Animal Resources, Kangwon National University, Chuncheon 200-701, Korea
}

Received February 21, 2014 /Revised July 24, 2014 / Accepted July 24, 2014

\begin{abstract}
Housefly (Musca domestica L.) maggots are used as biomedical material. Ethanolic extracts of fly maggot (EM) were orally administered to male rats at levels of 0 (control group), 4.0, 6.0, and $8.0 \mathrm{mg}$ per $100 \mathrm{~g}$ live weight for 40 days. Serum triglycerides, total cholesterol, and LDL-C decreased by 17.90, 17.60, and $16.37 \%$, respectively, whereas HDL-C increased by $20.48 \%$ in the EM group compared with these parameters in a control group $(p<0.05)$. Thymus and spleen weights dose-dependently increased by $21.42 \%$ and $21.42 \%$, respectively, but abdominal fat decreased by $39.66 \%$ after EM administration compared with that in the control group $(p<0.05)$. IgG, IgA, and $\operatorname{IgM}$ increased 35.14, 68.65, and $190.16 \%$, respectively, in the EM groups compared to the control group $(p<0.05)$. Bifidobacterium and Lactobacillus increased by $41.68 \%$ and $35.55 \%$, respectively, in the EM groups compared with the control group, and Bacteroides, Clostridium, Escherichia, and Streptococcus decreased by 24.96, 46.37, 25.00, and $34.05 \%$, respectively, in the EM groups compared with the control group $(p<0.05)$. Compared with the control group, total organic acids, acetic acid, and propionic acid increased by 31.11, 49.34, and $24.88 \%$, whereas butyric acid, isobutyric acid, valeric acid, and isovaleric acid decreased by 30.79 , $72.64,32.90$, and $63.16 \%$ respectively, in the EM groups $(p<0.05)$. These results suggest that EM has a bifidogenic effect on immune cell development, blood lipid levels, and abdominal fat reduction by increasing the production of organic acid and numbers of cecal microorganisms in animals.
\end{abstract}

Key words : Bifidogenic, blood lipid, housefly maggot, microorganisms, organic acid

\section{서 론}

우리나라 사망률 1 위인 암 다음으로 지질대사 이상에 기인 한 뇌혈관질환 및 심혈관질환이 2,3 위를 차지하는 것으로 알 려졌다. 육식 위주의 식생활에 의한 혈액 중성지방, 저밀도지 단백질, 혈당의 증가 및 인구 고령화로 인한 고지혈증, 당뇨병, 비만 등과 같은 대사증후군의 발생이 높아지고 있다[6, 13]. 인간의 대장은 건강과 질병에 기본적인 역할을 하는 무수한 미생물이 서식하고 있다. 이러한 장 환경은 영양소 공급, 상피 조직 발육조절, 숙주의 면역능력 및 비특이적 방어 저항성에 영향을 주기 때문에 건강과 웰빙을 조절한다[7]. 비피더스 활 성효과(Bifidogenic effect)란 장에서 비피더스균의 선택적 증 식으로 장 내 $\mathrm{pH}$ 를 낮추어 미생물의 균총유지, 유기산 생성, 면역활성, 혈액 지질대사를 조절해주는 생체기능을 말한다 $[4$, $8,14,28$. 천연물로부터 대사증후군의 예방 및 치료와 관련한

\footnotetext{
*Corresponding author

Tel : +82-33-250-8615, Fax : +82-33-259-5575

E-mail : sopark@kangwon.ac.kr

This is an Open-Access article distributed under the terms of the Creative Commons Attribution Non-Commercial License (http://creativecommons.org/licenses/by-nc/3.0) which permits unrestricted non-commercial use, distribution, and reproduction in any medium, provided the original work is properly cited
}

비피더스 활성인자를 위한 새로운 소재개발 연구가 집중되고 있다 $[4,6$, 9]. 인위적인 환경에서 사육된 집파리(Musca domestica L.)은 옥수수, 콩, 분유, 설탕을 배지로 하여 자라는 곤충 의생명소재로서의 잠재성이 있다. 파리 유충은 예부터 오곡충 으로 불러왔으며 유충은 독성이 전혀 없고 다양한 약리적 효 능이 알려졌다. 중약대사전에서 유충은 피를 맑게 하고 열을 내리며 성체총록에는 감질의 치료제로 소개되었다. 조선시대 의 본초강목에는 열병 발생 시 열을 내리는 데 효과가 있으며 본초편독에는 입술에 난 악성종기 치료에 처방한다고 명기되 어 있다[16, 20].

유충을 이용한 고질적인 상처감염 환자에 대한 치료 기술은 오래전부터 알려져 왔으며 항생제 내성균의 출현으로 화상 및 욕창환자에 대한 생체치료 기술이 새롭게 의학 분야에 접 목되기 시작했다 $[2,26]$. 유충 치료는 특히 Staphylococcus aureus와 같은 그람양성균에 감염된 환자의 치료에 권장되고 있 다[5]. 유충 분비물과 에탄올추출물로부터 MRSA, VRE 균주 에 대하여 강력한 항균활성을 지닌 $5-22 \mathrm{kDa}$ 의 항균펩타이드 가 알려졌다 $[1,3,11]$. 유충으로부터 추출한 단백질분획물 및 에탄올추출물의 간 손상 보호효과 $[16,29]$ 및 유충 분비물의 In vitro 항종양 및 항균활성에 관한 연구보고는 많이 알려져 있다 $[10,16]$. 그러나 유충으로부터 항균펩타이드를 함유하는 에탄올추출물의 혈액지질 감소, 면역세포 발육, 맹장미생물 
및 유기산 변화와 관련한 비피더스 활성효과는 보고된 것이 거의 없다.

본 연구는 랫드에게 인위적인 환경에서 사육하여 생산된 파리 유충으로부터 얻어진 에탄올추출물의 경구투여가 비피 더스 활성에 미치는 영향을 조사하였다.

\section{재료 및 방법}

\section{추출물의 제조}

$2 \sim 3$ 일령 유충을 $28^{\circ} \mathrm{C}$ 송풍건조기에서 말린 후 $500 \mathrm{~g}$ 을 150 ${ }^{\circ} \mathrm{C}$ 의 고온, $1,000 \mathrm{PSI}$ 로 30 분 간 압착, 추출해서 지질을 1 차로 $98 \%$ 제거하였다. 남아있는 지질을 헥산을 이용해서 지질을 완전히 제거하였고 탈지 유충 잔사를 얻었다. 탈지 유충 잔사 와 순수한 에탄올을 1:10의 비율로 혼합한 후 환류 냉각장치를 이용해서 유용물질을 추출하였다. $40^{\circ} \mathrm{C}$ 수욕 상에서 회전식농 축기(Eyela N-1000, Tokyo Rikakikai Co., Japan)로 감압, 농축 하여 $5 \mathrm{kDa}$ 의 항균펩타이드를 함유하는 단백질분획 추출물 $4.30 \%$ 를 얻었다. 항균펩타이드 분류 방법을 요약하면 아래와 같다. 파리유충에 Thermolysin을 처리하여 $37^{\circ} \mathrm{C}, 8$ 시간 배양 을 통해서 수용성 단백질 가수분해물을 조제하였다. 가수분해 물을 에탄올과 혼합한 다음 $-20^{\circ} \mathrm{C}$ 에서 24 시간 동안 정치한 후 여과해서 에탄올 추출물(Ethanolic extracts of fly maggot, $\mathrm{EM})$ 을 얻었다. 에탄올 추출물은 단백질 $95 \%$, 당질 $5 \%$ 를 함유 하였다. EM에서 MRSA strain 3595와 VRE strain 5117의 성장 억제 곡선과 최소억제 농도는 배양 후 농도 의존적으로 증가 한다는 사실을 확인하였다. $\mathrm{EM}$ 으로부터 항균펩타이드는 $\mathrm{Gel}$ Chromatography에 의해서 분리하였으며 RP-HPLC를 이용 하여 분석하였다[11, 16].

\section{실험설계}

동물실험은 유럽실험동물 취급면허 기준[25]에서 제시된 윤리적이고 과학적인 절차에 따라서 수행하였으며 강원 대학 교 동물실험윤리위원회(Institutional Animal Care and Use Committee, IACUC)의 승인을 얻었다. 랫드 수컷 SpragueDawley strain 40마리(평균 체중 $200 \mathrm{~g}$ )를 대한바이오링크(주) 로부터 공급받았다. 일반식이의 급여와 함께 1 주일간 환경적 응을 거친 후 40 일간 실험처리를 하였다. 처리구는 $\mathrm{EM}$ 의 투여 량에 따라서 4 개의 처리구로 구분하였으며(EM 0, 4.0, 6.0, 8.0 $\mathrm{mg} /$ 체중 $100 \mathrm{~g}$ ) 각 처리구당 10 마리씩 나누어 완전임의배치 하였고 각 케이지 당 1 마리씩 분리하여 사육하였다. 실험동물 사육실의 온도는 $20 \pm 2{ }^{\circ} \mathrm{C}$, 상대습도 $55 \pm 5 \%$ 로 유지하였다. 조 명은 야행성인 동물의 생물학적 특성을 고려하여 취급과정에 서 발생할 수 있는 실험절차상의 스트레스 최소화를 위하여 12시간 역전점등 주기(08:00-20:00 소등)로 조절하였다. 실험식 이는 AIN-93 [21]에 기초한 정제식이를 조제 후 펠렛 처리 후 물과 함께 자유급여하였다. 정제식이의 조성은 카제인(Casein- vitamin free) $20.0 \%$, 옥수수전분 $13.2 \%$, 말토덱스트린 $10.0 \%$, 설탕 $7.0 \%$, 대두유 $5.0 \%$, 분말셀룰로스 $5.0 \%$, AIN 93G 미네랄 혼합제 $1.00 \%$, AIN $93 \mathrm{G}$ 비타민 혼합제 $0.30 \%$, L-시스틴 $0.30 \%$, Choline bitartrate $0.25 \%$ 및 t-Butylhydroquinone $0.0014 \%$ 를 함유하였다.

\section{경구투여}

$\mathrm{EM}$ 을 매일 일정한 시간에 랫드용 직경 $1 \mathrm{~mm}$ 의 위관 (Gavage)을 이용해서 경구투여 하였다. EM을 공급하지 않은 대조구는 생리식염수 $1 \mathrm{ml}$, 시험처리구는 각각의 처리구에 해 당하는 $\mathrm{EM}$ 을 동일한 량의 생리식염수와 혼합해서 경구투여 하였다.

\section{혈액 채취 및 기관무게}

실험기간이 종료된 후 동물은 8시간 절식시킨 후 에틸에테 르로써 가볍게 마취시켰다. EDTA 처리된 $5 \mathrm{ml}$ 주사기와 바늘 $(2.5 \mathrm{~cm}, 21$-Gauge)를 이용하여 심장천공에 의해서 전혈 $2 \mathrm{ml}$ 를 채혈하였다. 전혈을 혈청분리 튜브(SST tube, BD, Falcon, USA) 속으로 수집하여 30 분 동안 상온에서 응고시킨 후 원심 분리 $(3,000 \mathrm{rpm}, 15$ 분)에 의해서 혈청을 얻었다. 간, 신장, 복부 지방, 비장 및 흥선을 채혈 후 즉시 떼어서 생리식염수로 혈액 을 씻어낸 다음 여과지로 흡착시켜 수분을 제거하고 기관의 무게를 측정하였다. 수집된 혈청은 $-20^{\circ} \mathrm{C}$ 냉동 보관하면서 생 화학적 분석에 이용하였다.

\section{혈액 지질}

혈청의 지질분획 중 Triglyceride, Total cholesterol, High density lipoprotein cholesterol (HDL-C), Low density lipoprotein cholestero (LDL-C)은 Diagnostic Kit (Sigma chemical $\mathrm{Co}_{\text {, }} \mathrm{St}$, Louis, $\mathrm{MO}, \mathrm{USA}$ )로써 분석하였다.

\section{혈청 면역단백질}

혈청의 면역단백질은 상업용 킷(Rat EIA kit, TKR, Japan)을 사용하여 ELISA (Enzyme-linked immunosorbent assay, Bethyl laboratories., Inc., USA)에 의해서 측정하였다. 제조사 의 매뉴얼에 따라서 처리하여 반응시킨 다음 Microplate reader (Molecular Devices, Inc., New York, USA)를 사용하여 450 $\mathrm{nm}$ 에서 각 well의 흡광도를 측정해서 표준물질 곡선에서 나 타난 값과 비교하여 계산하였다.

\section{맹장의 미생물}

장 내 미생물을 조사하기 위하여 Anaerobic chamber $(80 \%$ $\mathrm{N}_{2}, 10 \% \mathrm{CO}_{2}, 10 \% \mathrm{H}_{2}$ )에서 맹장을 채취하였다. 맹장내용물을 멸균 생리식염수 $10 \mathrm{ml}$ 를 함유하는 vial 속으로 넣어 균질화하 였다. 균질물을 $10^{-2}$ 에서 $10^{-8}$ 까지 연속적으로 희석하였다. 희 석액 $100 \mathrm{ul}$ 를 멸균된 배지 속으로 각각 3 반복씩 분주한 후 
플레이트를 48 시간 동안 $37^{\circ} \mathrm{C}$ 에서 배양 후 계수하였다. 배지 는 Bifidobacterium spp. (Modified Columbia agar, Oxoid), Lactobacillus spp. (MRS agar, Oxoid), Bacteroides spp. (Bacteroids bile esculin agar, Difco), Clostridium spp. (Egg yolk agar, Difco), Escherichia coli (McConkey's agar, BBL, Baltimore, MD), Streptococcus spp. (SF agar, Difco)를 사용하였다. 맹장내용물 $\mathrm{g}$ 당 균수 로그 값( $\log 10 \mathrm{CFU}$, colony forming unit/g of fresh cecum content)을 계산하였다.

\section{맹장의 유기산}

장 내 유기산으로서 Acetic acid, Propionic acid, Butyric acid, Isobutyric acid, Valeric acid 그리고 Isovaleric acid의 농도는 4-Methyl normal valeric acid (Sigma Co. Ltd., USA) 를 Internal standard로써 이용하여 Gas chromatographic system (model GC-15A, Shimadzu Corp., Kyoto, Japan)에 의해 서 측정하였다. 맹장내용물 약 $5 \mathrm{~g}$ 을 스크류캡 튜브에서 증류 수 $5 \mathrm{ml}$ 를 이용하여 혼합, 균질화한 다음 $4{ }^{\circ} \mathrm{C}, 3,000 \mathrm{rpm}$ 에서 10 분간 원심분리하였다[30]. 상등액 $1 \mathrm{ml}$ 를 앰플병으로 옮긴 후 30 분 이상 얼음상자 위에서 유지하였고 $0.2 \mathrm{ml}$ 의 Metaphosphoric acid solution을 첨가하였다. GC 분석하기 전에 $3,000 \mathrm{rpm}$ 에서 10 분간 원심분리하였다. GC는 불꽃이온화검 출기와 Polyethylene glycol column (Hewlett Packard, 30 $\mathrm{m} \times 320 \mu \mathrm{m} \times 0.50 \mu \mathrm{m})$ 가 부착되었으며 운반가스로써 고순도 $\mathrm{N}_{2}(1.8 \mathrm{ml} / \mathrm{min})$ 를 이용하여 $100-150^{\circ} \mathrm{C}$ 에서 분석하였다.

\section{통계처리}

분석된 자료의 통계처리는 SAS 프로그램을 이용하였으며 각 처리구의 평균과 표준오차를 구하고 분산분석을 실시한 다음 던칸의 다중검정법에 의하여 $95 \%$ 수준에서 유의성을 검 정하였다[24].

\section{결과 및 고찰}

\section{복강지방 감소 및 면역세포 중량}

실험기간 동안 식이섭취량 $(40.12 \pm 0.72 \mathrm{~g}$ /일 $)$ 과 체중 증가량 $(7.17 \pm 0.86 \mathrm{~g} /$ 일 $)$ 은 처리구 간 유의성이 나타나지 않았다. 영양 소 함량이 동일한 정제된 실험사료를 급여하면서 서로 다른 수준의 $\mathrm{EM}$ 을 경구 투여한 랫드의 기관 및 면역세포 발육에 따른 무게변화를 조사한 결과는 Table 1과 같다. 간 및 신장 무게는 모든 처리구에서 통계적 유의차가 없었다. 복강지방은 $\mathrm{EM}$ 투여군이 대조군과 비교하였을 때 $39.66 \%$ 까지 유의하게 낮아졌다( $p \times 0.05) . \mathrm{EM}$ 농도 의존에 따른 복강지방 감소효과는 $8.0,6.0,4.0 \mathrm{mg}$ 순서로 낮아졌으나 4.0 와 $6.0,6.0$ 과 $8.0 \mathrm{mg}$ 사이의 복강지방은 유의차가 나타나지 않았다. 본 연구결과, $\mathrm{EM}$ 투여군에서 복강지방이 낮았던 점은 혈액 내 중성지방과 혈당이 감소함으로써(Table 2) 이러한 매개변수들이 내장조직
Table 1. Effects of the oral administation of ethanolic extracts of fly maggot, EM) on organ weight in rats

(g/100 g of body weight)

\begin{tabular}{lcccc}
\hline \multirow{2}{*}{ Organ } & \multicolumn{4}{c}{ EM mg/100 g of body weight } \\
\cline { 2 - 5 } & 0 & 4.0 & 6.0 & 8.0 \\
\hline Liver & $3.47 \pm 0.91$ & $3.45 \pm 0.55$ & $3.41 \pm 0.85$ & $3.45 \pm 0.42$ \\
Kidney & $0.66 \pm 0.20$ & $0.66 \pm 0.20$ & $0.66 \pm 0.01$ & $0.65 \pm 0.31$ \\
Abdominal fat & $0.58 \pm 0.25^{\mathrm{a}}$ & $0.42 \pm 0.25^{\mathrm{b}}$ & $0.38 \pm 0.20^{\mathrm{bc}}$ & $0.35 \pm 0.25^{\mathrm{c}}$ \\
Thymus & $0.14 \pm 0.06^{\mathrm{b}}$ & $0.17 \pm 0.12^{\mathrm{a}}$ & $0.17 \pm 0.15^{\mathrm{a}}$ & $0.17 \pm 0.12^{\mathrm{a}}$ \\
Spleen & $0.28 \pm 0.17^{\mathrm{b}}$ & $0.33 \pm 0.01^{\mathrm{a}}$ & $0.33 \pm 0.01^{\mathrm{a}}$ & $0.34 \pm 0.01^{\mathrm{a}}$ \\
\hline
\end{tabular}

Means \pm SD $(n=10)$.

$a, b, c$ Means with different superscripts in the same row are significantly different $(p<0.05)$.

Table 2. Effect of the oral administration of ethanolic extracts of fly maggot, EM) on serum lipid profile and glucose in rats

$(\mathrm{mg} / \mathrm{dl})$

\begin{tabular}{lcccc}
\hline \multirow{2}{*}{ Item } & \multicolumn{4}{c}{ EM mg/100 g of body weight } \\
\cline { 2 - 5 } & 0 & 4.0 & 6.0 & 8.0 \\
\hline TG & $167.6 \pm 0.79^{\mathrm{a}}$ & $142.07 \pm 0.81^{\mathrm{b}}$ & $137.6 \pm 0.36^{\mathrm{c}}$ & $137.6 \pm 0.65^{\mathrm{c}}$ \\
TC & $97.74 \pm 0.49^{\mathrm{a}}$ & $83.52 \pm 0.50^{\mathrm{b}}$ & $83.56 \pm 0.55^{\mathrm{b}}$ & $80.54 \pm 0.53^{\mathrm{c}}$ \\
LDL-C & $32.63 \pm 0.71^{\mathrm{a}}$ & $17.49 \pm 0.29^{\mathrm{b}}$ & $17.99 \pm 0.71^{\mathrm{b}}$ & $15.40 \pm 0.70^{\mathrm{c}}$ \\
HDL-C & $31.59 \pm 0.47^{\mathrm{b}}$ & $37.61 \pm 0.35^{\mathrm{a}}$ & $38.06 \pm 0.16^{\mathrm{a}}$ & $37.61 \pm 0.37^{\mathrm{a}}$ \\
\hline
\end{tabular}

Means \pm SD $(n=10)$.

$a, b, c$ Means with different superscripts in the same row are significantly different $(p<0.05)$.

으로 이동한 량이 낮아졌기 때문으로 생각할 수 있다. 또한 맹장 내 유익한 Bifidobacteria, Lactobacillus의 선택적인 증식 (Table 4)에 의해서 나타난 생체활성 효과로 볼 수 있다. 혈액 지질과 혈당은 생체 조직으로 이동하여 에너지 발생에 쓰여지 고 남은 부분은 복강지방에 축적된다[15]. 그러므로 $\mathrm{EM}$ 투여 군에서 복강지방이 감소한 점은 $\mathrm{EM}$ 내 함유된 항균펩타이드 의 생체활성 작용에 의해서 혈액 지질의 량이 감소하였고 궁 극적으로 복강조직에 이동된 지질의 량 역시 줄어들어 나타난 현상으로 볼 수 있다. Bifidobacteria, Lactobacillus는 혈액 지질 대사를 조절하여 줌으로써 중성지방과 콜레스테롤을 낮춘다 $[9,18,22]$.

면역세포인 흥선과 비장은 대조구와 비교할 때 $\mathrm{EM}$ 투여군 에서 각각 $121.42,121.42 \%$ 유의하게 증가하였으나 $(p<0.05)$ $\mathrm{EM}$ 투여군 사이의 유의차는 나타나지 않았다. 본 결과는 EM 에 포함된 항균펩타이드 작용으로 나타난 맹장에서 Bifidobacteria와 Lactobacillus의 증식(Table 4) 및 유기산 증가(Table 5) 에 기인한 비피더스 활성효과로 볼 수 있다[15]. 항균펩타이드 는 Bifidobacteria와 Lactobacillus 증식과 함께 유기산을 높이는 것으로 보고되었다[23, 27]. 동물의 맹장 환경조성에 유익한 총유기산은 면역세포 발육을 자극하여 면역기관의 무게를 높 여주고 면역물질의 농도를 증가시켜준다[22]. 한편, $\mathrm{EM}$ 투여 
군에서 비장이나 흥선 같은 면역기관이 비대해졌다고 혹은 면역세포가 양적으로 증가되었다고 면역기능이 증가되었다 고 보기에는 약간 무리가 있는 것으로 볼 수 있다. 면역기관 무게증가가 면역세포 표현형, 면역세포 증식 또는 $\operatorname{IgG}$ 생산에 확고한 효과를 나타내지 않는다[30]. 따라서 이를 보충해 줄 수 있는 추가적인 연구가 필요하다고 생각된다. 흥선과 비장 은 항체생산을 위한 중요한 면역기관으로써 여기에 제시한 흥선지수에 관한 자료는 $\mathrm{EM}$ 의 항균활성 펩타이드가 랫드에 서 흥선세포의 발육을 향상시켰을 것으로 볼 수 있다. 점액성 면역은 체액성면역의 중요한 부분이며 $\operatorname{IgA}$ 는 점액성면역의 작용자(effector)이다. 그것은 점막표면에서 가장 지배적인 항 체이며 소화관에서 병원체 침입에 저항하는 수동적 면역보호 를 실행한다 $[12,15,30]$. 본 결과는 $\mathrm{EM}$ 이 보다 많은 항체를 생산하기 위하여 체액성면역시스템을 자극할 수 있음을 보여 준다.

\section{혈액 지질}

$\mathrm{EM}$ 을 경구투여 한 랫드에서 혈액 지질분획 수준의 변화는 Table 2에서 보는바와 같다. 혈액 중성지방, 총콜레스테롤 및 LDL-C는 EM 투여군이 대조군과 비교할 때 각각 $17.90,17.60$, $52.80,16.37 \%$ 유의하게 감소하였다( $p \times 0.05)$. EM 투여군 사이 의 중성지방은 EM 4.0 투여군이 가장 높았으나 6.0 과 $8.0 \mathrm{mg}$ 사이의 통계적인 유의차는 없었다. $\mathrm{EM}$ 투여군 사이의 총콜레 스테롤, LDL-C는 EM $8.0 \mathrm{mg}$ 투여군이 가장 높았으나 4.0 과 $6.0 \mathrm{mg}$ 사이의 통계적인 유의차는 없었다. $\mathrm{HDL}-\mathrm{C}$ 는 $\mathrm{EM}$ 을 경 구투여 한 이후 $120.48 \%$ 까지 유의하게 증가하였으나 $(\beta \times 0.05)$ $\mathrm{EM}$ 투여군 사이의 통계적인 유의차는 없었다. $\mathrm{EM}$ 을 투여한 동물에서 혈액지질의 감소결과는 $\mathrm{EM}$ 에 들어있는 항균펩타이 드에 의해서 나타난 Bifidobacteria와 Lactobacillus 성장에 의한 비피더스 활성효과로 볼 수 있다[14, 15, 22, 27]. 항균펩타이드 는 유해세균의 막전위 파괴 및 자기면역성에 의해서 Bifidobacteria 와 Lactobacillus 균수를 증가시키는 것으로 알려졌다 $[8$, 15]. Bifidobacteria 및 Lactobacillus 는 혈액 지질대사를 조절하여 줌으로써 중성지방과 콜레스테롤을 낮춘다[18, 22]. 결과는 $\mathrm{EM}$ 이 사람에서 대사성증후군을 예방하는데 도움이 될 수 있 는 혈액지질을 낮춘다는 새로운 사실을 발견하였다. $\mathrm{Ha}$ (2011)는 Bifidobacteria와 Lactobacillus는 고지방식이를 섭취한 비만 랫드에서 혈액 지질 감소효과를 갖는다고 하였다[9]. 혈 액 내 중성지방과 LDL-C가 높으면 심근경색 및 동맥경화증과 같은 심혈관질환으로 인한 사망률과 비만을 높이지만 이와 반대로 HDL-C는 이러한 질환을 예방하는데 크게 도움이 되 는 것으로 알려졌다[16, 19]. LDL은 동맥에서 콜레스테롤 축적 을 위한 대부분의 지질 수송단백질로서 간에서 혈액으로 콜레 스테롤 에스터를 이동하고 신체 여러부위의 상피세포로 운반 해주는 기능을 수행한다. HDL은 동맥에서 간으로 콜레스테롤 을 역수송하는 지질 수송단백질로서 혈액 중 HDL-C의 증가
Table 3. Effect of the oral administration of ethanolic extracts of fly maggot, EM) on $\operatorname{IgG}, \operatorname{IgM}$ and $\operatorname{IgA}$ in rats

$(\mathrm{ng} / \mathrm{ml})$

\begin{tabular}{crrrr}
\hline \multirow{2}{*}{$\begin{array}{c}\text { Immuno- } \\
\text { globulin }\end{array}$} & \multicolumn{4}{c}{ EM mg/100 g of body weight } \\
\cline { 2 - 5 } IgG & \multicolumn{1}{c}{$48.77 \pm 0.25^{\mathrm{c}}$} & $30.13 \pm 0.26^{\mathrm{b}}$ & $38.67 \pm 0.35^{\mathrm{a}}$ & $38.88 \pm 0.15^{\mathrm{a}}$ \\
IgM & $8.20 \pm 0.50^{\mathrm{c}}$ & $8.93 \pm 0.40^{\mathrm{b}}$ & $13.73 \pm 0.25^{\mathrm{a}}$ & $13.83 \pm 0.15^{\mathrm{a}}$ \\
IgA & $1.93 \pm 0.40^{\mathrm{c}}$ & $3.13 \pm 0.25^{\mathrm{b}}$ & $5.60 \pm 0.56^{\mathrm{a}}$ & $5.50 \pm 0.43^{\mathrm{a}}$ \\
\hline
\end{tabular}

Means \pm SD $(\mathrm{n}=10)$.

${ }_{a, b, c}$ Means with different superscripts in the same row are significantly different $(p<0.05)$.

는 혈액과 조직으로부터 간으로 콜레스테롤 수송능력을 높여 주고 콜레스테롤의 역수송에 의해서 혈액 콜레스테롤을 제거 해준다. 따라서 LDL-C가 높으면 건강에 해롭기 때문에 "나뺀 콜레스테롤"이라고 부르지만 HDL-C은 “좋은 콜레스테롤"이 라고 부른다[16, 19]. 한편, 혈액 지질수준에 있어서 $\mathrm{EM}$ 의 효과 를 보기 위한 비만모델동물을 이용한 추가적인 실험이 필요한 것으로 사료된다.

\section{혈청 면역단백질}

$\mathrm{EM}$ 을 경구투여 한 후 혈청 면역단백질의 변화는 Table 3에 서 보는 바와 같다. 혈청 $\mathrm{IgG}, \mathrm{IgA}, \mathrm{IgM}$ 농도는 대조군과 비교 할 때 $\mathrm{EM}$ 투여군에서 각각 $135.14,168.65,290.16 \%$ 까지 유의 하게 증가하였다 $(p<0.05) . \mathrm{EM}$ 투여군 사이의 면역단백질은 $\mathrm{EM} 6.0,8.0 \mathrm{mg}$ 투여군이 $4.0 \mathrm{mg}$ 투여군과 비교할 때 높았으나 6.0 과 $8.0 \mathrm{mg}$ 사이의 통계적인 유의차는 없었다. 6.0 과 $8.0 \mathrm{mg}$ 투여군 사이의 통계적 유의차는 없었다. $\mathrm{EM}$ 투여군에서 $\mathrm{IgG}$, $\mathrm{IgA}, \mathrm{IgM}$ 농도가 높았던 점은 면역세포 발육증가에 따른 면역 기관의 무게 증가(Table 1)로부터 나타난 결과이다. 대조군(일 반적인 상황)에 비교하여 면역기관의 크기가 커지고 면역단백 질이 증가되었다는 현상이 생명체의 fitness 측면에서 좋은 변 화라고 보기에는 논란의 여지가 있다. 선천적 혹은 후천적 면 역결핍 현상을 나타내는 질환자의 경우 면역기능을 향상시키 는 것이 긍정적인 변화이겠지만 오히려 과한 면역반응이 문제 라고 할 수 있는 알레르기 질환이나 자가면역질환과 관련한 점은 여전히 풀어야 할 숙제이다. 면역세포의 발육 증가는 혈 액으로 분비되는 면역물질의 농도를 높이는 데 영향을 주었으 며 이는 $\mathrm{EM}$ 을 섭취한 동물의 맹장에서 나타난 비피더스 활성 효과일 것으로 추정할 수 있다 $[7,15,18]$. 맹장의 Bifidobacteria 와 Lactobacillus는 과립구의 비특이적 면역세포 활성 및 혈액 중 면역물질의 순환농도를 높여주는데 있어서 중요한 작용을 한다[22]. $\mathrm{EM}$ 을 투여한 랫드에서 혈액 $\mathrm{IgG}$ 농도의 증가는 체 액성 면역증가를 위한 추출물에 함유된 항균펩타이드의 효율 성이 높다는 점을 나타낸다[15]. 면역단백질은 골수의 B-세포 에서 생성되고 $\mathrm{IgG}$ 는 혈액에서 가장 높으며 생물학적 면역력 증진 및 혈액 IgG titer는 체액성 면역 마커이다[12, 15]. 면역단 
Table 4. Effect of the oral administration of ethanolic extracts of fly maggot, EM) on cecal microorganisms in rats $\left(\log _{10} \mathrm{cfu} / \mathrm{g}\right.$ fresh cecal content)

\begin{tabular}{lcccc}
\hline \multirow{2}{*}{ Microorganisms s } & \multicolumn{4}{c}{ EM mg/100 g of body weight } \\
\cline { 2 - 5 } & 0 & 4.0 & 6.0 & 8.0 \\
\hline Bifidobacterium & $5.83 \pm 0.32^{\mathrm{c}}$ & $7.20 \pm 0.25^{\mathrm{b}}$ & $8.26 \pm 0.31^{\mathrm{a}}$ & $7.19 \pm 0.17^{\mathrm{b}}$ \\
Lactobacillus & $6.02 \pm 0.29^{\mathrm{b}}$ & $8.12 \pm 0.27^{\mathrm{a}}$ & $8.16 \pm 0.33^{\mathrm{a}}$ & $8.06 \pm 0.24^{\mathrm{a}}$ \\
Bacteroids & $6.17 \pm 0.03^{\mathrm{a}}$ & $5.30 \pm 0.25^{\mathrm{b}}$ & $5.31 \pm 0.36^{\mathrm{b}}$ & $4.36 \pm 0.23^{\mathrm{c}}$ \\
Clostridium & $5.78 \pm 0.21^{\mathrm{a}}$ & $3.75 \pm 0.18^{\mathrm{b}}$ & $3.56 \pm 0.19^{\mathrm{b}}$ & $3.10 \pm 0.12^{\mathrm{c}}$ \\
E. coli & $3.16 \pm 0.19^{\mathrm{a}}$ & $2.37 \pm 0.25^{\mathrm{b}}$ & $2.37 \pm 0.36^{\mathrm{b}}$ & $2.39 \pm 0.16^{\mathrm{b}}$ \\
Streptococcus & $4.64 \pm 0.27^{\mathrm{a}}$ & $3.07 \pm 0.25^{\mathrm{b}}$ & $3.16 \pm 0.26^{\mathrm{b}}$ & $3.06 \pm 0.30^{\mathrm{b}}$ \\
\multicolumn{1}{c}{ aureus } & & & &
\end{tabular}

Means \pm SD $(n=10)$.

$a, b, c$ Means with different superscripts in the same row are significantly different $(p<0.05)$.

백질은 $\mathrm{IgM}$ 을 $\mathrm{IgG}$ 로 전환하는 기전 또는 $\mathrm{IgA}$ 의 면역능력을 성공적으로 발휘하는데 있어서 중요하며 비장, 흥선 및 림프 기관에 의존하고 있다[15]. 한편, 면역기능의 변화를 보기 위해 서는 특정 면역질환모델 동물(알레르기모델, 자가면역질환모 델 등)을 이용한 추가적인 연구가 필요한 것으로 생각한다.

\section{맹장 미생물}

$\mathrm{EM}$ 을 경구투여 한 후 맹장 내용물의 미생물 변화를 측정한 결과는 Table 4 에서 보는바와 같다. Bifidobacterium과 Lactobacillus는 대조군과 비교할 때 EM 투여군에서 각각 141.68, $135.55 \%$ 까지 유의하게 증가하였다( $p<0.05)$. EM 투여군 사이 의 Bifidobacterium은 EM $6.0 \mathrm{mg}$ 투여군이 가장 높았고 4.0 과 $8.0 \mathrm{mg}$ 사이의 통계적 유의차는 없었으며 Lactobacillus는 투여 군 사이의 통계적 유의차가 없었다. Bacteroides와 Clostridium 은 $\mathrm{EM}$ 을 공급한 이후 대조군에 비해서 각각 $24.96,46.37 \%$ 까 지 유의하게 감소하였다 $(p<0.05)$. EM 투여군 사이의 Bacteroides와 Clostridium은 $8.0 \mathrm{mg}$ 투여군이 가장 낮았으며 4.0 와 $6.0 \mathrm{mg}$ 사이의 통계적 유의차는 없었다. Escherichia와 Streptococcus는 대조군과 비교할 때 $\mathrm{EM}$ 투여군에서 각각
$25.00,34.02 \%$ 까지 유의하게 감소하였다( $p<0.05)$. EM 투여군 사이의 Escherichia와 Streptococcus는 EM 투여군 사이의 통계 적인 유의차가 없었다.

본 연구결과 $\mathrm{EM}$ 을 공급해준 동물의 맹장에서 Bifidobacterium, Lactobacillus의 성장이 촉진되었고 혈액 중 면역물질의 농도가 높았던 점은 $\mathrm{EM}$ 에 함유된 항균활성 펩타이드의 작용으로부 터 나타난 비피더스 활성효과로 사료된다 $[15,18]$. 소화관에서 미생물은 장 상피세포에서 필요한 에너지를 제공해주는 발효 산물의 생성, 소화관 면역시스템 자극, 비타민 K 합성 및 외인 성 병원균의 침착을 방지해주는 중요한 역할을 한다[27]. Bifidobacteria와 Lactobacillus는 잠재성 병원균과 영양소 및 장 부착 부위에 대한 경쟁을 하여 장내 병원균의 숫자를 낮춘다. Bifidobacteria와 Lactobacillus는 Escherichia coli와 같은 유해세균 의 성장을 억압하는 박테리오신을 분비하고 젖산, 초산과 같 은 유기산을 생성한다. 이러한 기질은 장 내 병원성 미생물의 응집을 억제한다[14, 23]. EM을 공급받은 동물의 맹장에서 유 익한 Bifidobacterium과 Lactobacillus 숫자의 증가 및 유해한 Bacteroides, Clostridium, Escherichia coli, Streptococcus 균수의 감소는 이러한 기전에 기인한 것으로 볼 수 있다[14, 15].

\section{맹장 유기산}

$\mathrm{EM}$ 을 경구투여 한 후 맹장에서 유기산의 변화는 Table 5에 제시되었다. 총유기산, 초산, 프로피온산은 대조군과 비교할 때 $\mathrm{EM}$ 투여군에서 각각 $131.11,149.34,124.88 \%$ 유의하게 증 가하였다( $p<0.05)$. 뷰티르산, 이소뷰티르산, 발레르산, 이소발 레르산은 대조군과 비교할 때 $\mathrm{EM}$ 투여군에서 각각 30.79, $72.64,32.90,63.16 \%$ 유의하게 감소하였다( $p \times 0.05)$. $\mathrm{EM}$ 투여군 사이의 총유기산은 $4.0 \mathrm{mg}$ 투여군이 가장 높았고 6.0 과 8.0 $\mathrm{mg}$ 사이의 통계적 유의차는 없었으며 초산은 $8.0 \mathrm{mg}$ 투여군 이 가장 높았으며 4.0 과 $6.0 \mathrm{mg}$ 사이의 통계적 유의차는 없었 다. 프로피온산은 $8.0 \mathrm{mg}$ 투여군이 가장 낮았고 4.0 과 $6.0 \mathrm{mg}$ 사이의 통계적 유의차는 없었다. $\mathrm{EM}$ 투여군 사이의 뷰티르산 과 발레르산은 농도 의존적으로 낮아졌다. 이소뷰티르산은 $4.0 \mathrm{mg}$ 투여군이 가장 높았고 6.0 과 $8.0 \mathrm{mg}$ 사이의 통계적

Table 5. Effects of the oral administration of ethanolic extracts of fly maggot, EM) on cecal organic acid in rats

(Unit: $\mu \mathrm{mol} / \mathrm{g}$ of cecal content)

\begin{tabular}{lcccc}
\hline \multirow{2}{*}{ Organic acids } & \multicolumn{4}{c}{ EM mg/100 g of body weight } \\
\cline { 2 - 4 } & 0 & 4.0 & 6.0 & 8.0 \\
\hline Acetic acid & $48.28 \pm 0.37^{\mathrm{c}}$ & $69.64 \pm 0.53^{\mathrm{b}}$ & $70.25 \pm 0.93^{\mathrm{b}}$ & $72.10 \pm 0.26^{\mathrm{a}}$ \\
Propionic acid & $17.52 \pm 0.37^{\mathrm{c}}$ & $21.60 \pm 0.23^{\mathrm{a}}$ & $21.88 \pm 0.15^{\mathrm{a}}$ & $20.97 \pm 0.12^{\mathrm{b}}$ \\
Butyric acid & $6.17 \pm 0.25^{\mathrm{a}}$ & $5.31 \pm 0.47^{\mathrm{b}}$ & $4.45 \pm 0.13^{\mathrm{c}}$ & $4.27 \pm 0.86^{\mathrm{d}}$ \\
Isobutyric acid & $1.17 \pm 0.30^{\mathrm{a}}$ & $1.16 \pm 0.03^{\mathrm{a}}$ & $0.35 \pm 0.07^{\mathrm{b}}$ & $0.32 \pm 0.05^{\mathrm{b}}$ \\
Valeric acid & $4.68 \pm 0.08^{\mathrm{a}}$ & $4.12 \pm 0.08^{\mathrm{b}}$ & $3.84 \pm 0.08^{\mathrm{c}}$ & $3.14 \pm 0.11^{\mathrm{d}}$ \\
Isovaleric acid & $0.95 \pm 0.09^{\mathrm{a}}$ & $0.65 \pm 0.06^{\mathrm{b}}$ & $0.36 \pm 0.06^{\mathrm{c}}$ & $0.35 \pm 0.07^{\mathrm{c}}$ \\
\hline Total & $78.77 \pm 0.33^{\mathrm{c}}$ & $102.48 \pm 0.29^{\mathrm{a}}$ & $101.13 \pm 0.56^{\mathrm{b}}$ & $101.15 \pm 0.46^{\mathrm{b}}$ \\
\hline
\end{tabular}

Means \pm SD $(n=10) .{ }^{a, b, c, d}$ Means with different superscripts in the same row are significantly different $(p<0.05)$. 
유의차는 없었으며 이소발레르산은 $4.0 \mathrm{mg}$ 투여군이 가장 높 았으며 6.0 과 $8.0 \mathrm{mg} \mathrm{http://www.ncbi.nlm.nih.gov/pubmed?}$ term $=$ Gunde-Cimerman \% 20N\%5BAuthor\%5D\&cauthor=true\&cauthor_uid=18436596사이의 통계적 유의차는 없 었다. 한편, 주요 유기산인 lactic acid는 측정하지 않았기 때문 에 이에 대한 추가적인 정량이 필요할 것으로 본다. $\mathrm{EM}$ 의 콜 레스테롤 감소효과는 지질 매개변수에 대한 각 변화가 짧은 사슬지방산에 의해 유도될 수 있는 간 조직의 대사적응의 결 과일 것으로 가설한다. $\mathrm{EM}$ 투여군의 맹장에서 장내 환경에 유익하고 면역능력 향상에 기여하는 총 유기산, 초산과 프로 피온산이 증가한 반면에 장 내 환경에 유해한 뷰티르산과 발 레르산이 감소한 점은 동물의 맹장에서 비피더스균의 선택적 증식에 의한 비피도스 활성효과에 기인한 것으로 생각할 수 있다[8]. Bifidobacteria는 병원성 미생물의 성장을 억압할 수 있 는 짧은 사슬지방산을 생성하여 맹장의 $\mathrm{pH}$ 를 낮춘다. 초산, 프로피온산은 생체 콜레스테롤 합성을 억압하고 혈액 콜레스 테롤을 낮추는 것으로 보고되었다[8]. 본 연구는 동물에서 $\mathrm{EM}$ 이 in vivo 비피더스 활성효과를 갖는다는 점을 발견한 최초의 보고이다.

결론적으로, $\mathrm{EM} 4 \mathrm{mg}$ 수준을 공급받은 동물의 맹장에서 미생물 균총, 유기산, 면역세포발육, 면역단백질 및 혈액지질 개선과 관련한 비피더스 활성효과를 발견하였다. 본 연구에서 발견한 $\mathrm{EM}$ 의 비피더스 활성효과는 $\mathrm{EM}$ 에 함유되어있는 항균 펩타이드의 작용으로 볼 수 있으며 $\mathrm{EM}$ 은 질병예방을 위한 곤충 의생명소재로서 유용하게 사용할 수 있을 것으로 본다.

\section{감사의 글}

이 논문은 2009년도 농림축산식품부 기술개발사업 자유공 모연구비 지원으로 진행되었으며 2013년도 강원대학교 포스 트닥 연구비 지원에 감사를 드립니다.

\section{References}

1. Bexfield, A., Nigam, Y., Thomas, S. and Ratcliffe, N. A. 2004. Detection and partial characterisation of two antibacterial factors from the excretions/secretions of the medicinal maggot Lucilia sericata and their activity against methicillin-resistant Staphylococcus aureus (MRSA). Microbes Infect 6, 1297-1304.

2. Bonn, D. 2000. Maggot therapy: an alternative for wound infection. Lancet 356, 1174.

3. An, C., Li, D. and Du, R. 2004. Analysis of antibacterial-relative proteins and peptides in housefly larvae. Wei Sheng Yan Jiu 33, 86-88.

4. Costabile, A., Kolida, S., Klinder, A., Gietl, E., Bauerlein, M., Frohberg, C., Landschutze, V. and Gibson, G. R. 2010. A double-blind, placebo-controlled, cross-over study to establish the bifidogenic effect of a very-long-chain inulin ex- tracted from globe artichoke (Cynara scolymus) in healthy human subjects. Br J Nutr 104, 1007-1017.

5. Domen, J., Ale, L., Klemen, Z., Dragica, S. and Nina, G. C. 2008. Selective antimicrobial activity of maggots against pathogenic bacteria. J Med Microbiol 57, 617-625.

6. Eckel, R. H., Grundy, S. M. and Zimmer, P. Z. 2005. The metabolic syndrome. Lancet 365, 1415-1428.

7. Fanaro, S. M., Berit, B., Rossana, V., Vittorio, F., Claudio, P. Q., Luis, A., Federico, S. A., Katharina, E. S., Gü, Z., Richard, S. and Michael, B. 2009. Galacto-oligosaccharides are bifidogenic and safe at weaning: A double-blind randomized multicenter study. J Pediatr Gastroenterol Nutr 48, 82-88

8. Gibson, G. R. and Rastall, R. A. 2006. Prebiotics: Development and application. John Wiley and Sons, Ltd., USA.

9. Ha, N. J. 2011. Antiobesity and lipid-lowering effects of Bifidobacterium spp. in high fat diet-induced obese rats. Lipids Health Dis 10, 116-125.

10. Jaklic, D., Lapanje, A., Zupancic, K., Smrke, D. and Gunde-Cimerman, N. Selective antimicrobial activity of maggots against pathogenic bacteria.N. 2008. Selective antimicrobial activity of maggots against pathogenic bacteria. J Med Microbiol 57, 617-625.

11. Jang, A., Cho, C. R., Park, B. S. and Yoon, K. J. 2007. Seperation of antibaterial low molecular peptides from Musca domesica maggot against methicillin-resistant Staphylococcus aureus (MRSA) and vancomycin resistant enterococcus (VRE), 2007 International Symposium and Annual Meeting. Korean Soc Food Sci Nutr October, 275.

12. Latvala, J., Hietala, J., Koivisto, H., Anttila, P. and Niemela, O. 2005. Immune response to ethanol metabolites and cytokine profiles differentiate alcoholics with or without liver disease. Am J Gastroenterol 100, 1303-1310.

13. Liu, X., Zeng, A., Song, T., Li, L., Yang, F., Wang, Q., Wu, B., Liu, Y. and Zhi, X. 2011. Hypocholesterolemic effects of n-[(2-hydroxy-3-n, n-dimethyl hexadecyl ammonium) propyl] chitosan chloride in high-fat-diet induced rats. J Biomater Sci Polym Ed 23, 1107-1114.

14. Lomax, A. R., Cheung, L. V., Tuohy, K. M., Noakes, P. S., Miles, E. A. and Calder, P. C. 2012. B2-1 Fructans have a bifidogenic effect in healthy middle-aged human subjects but do not alter immune responses examined in the absence of an in vivo immune challenge: results from a randomised controlled trial. Br J Nutr 108, 1818-1828.

15. Park, B. S. 2008. Bifidogenic effects of inuloprebiotics in broiler chickens. J Life Sci 18, 1693-1699.

16. Park, S. O. and Park, B. S. 2012. Effects of grain larvae extracts on hepatotoxicity and blood lipid in obese rats. I Anim Vet $A d v$ 11, 988-994.

17. Park, S. O., Park, B. S. and Oh, J. S. 2010. Antibacterial activity of housefly maggot extracts against MRSA and VRE. $J$ Environ Biol 31, 865-871.

18. Patterson, J. A. and Burkholder, K. M. 2003. Application of prebiotics in poultry production. Poult Sci 82, 627-631.

19. da Luz P. L.,, Favarato, D., Faria-Neto, J. R. Jr., Lemos, P. and Chagas, A. C. 2008. High ratio of triglycerides to 
HDL-cholesterol predicts extensive coronary disease. Clinics 63, 427-432.

20. Ratcliffe, N. A., Mello, C. B., Garcia, E. S., Butt, T. M. and Azambuja, P. 2011. Insect natural products and processes: New treatments for human disease. Insect Biochem $\mathrm{Mol} \mathrm{Biol}$ 41, 747-842.

21. Reeves, P. G., Nielsen, F. J. and Fahey, G. C. Jr. 1993. AIN-93 purified diets for laboratory rodents: final report of the American Institute of Nutrition ad hoc writing committee on the reformulation of the AIN-76A rodent diet. J Nutr 123, 1939-1951.

22. Roberfroid, M. B. 2000. Prebiotics and probiotics: are they functional foods. Am J Clin Nutr 71, 1682S-1687S.

23. Rolfe, R. D. 2000. The role of probiotic cultures in the control of gastrointestinal health. J Nutr 130, 396S-402S.

24. SAS. 2005. SAS/STAT User's Guide: Statistics. Version 6.0. SAS Institute Inc., Cary, North Carolina. USA.

25. Scot PIL training manual. 1994. Glasgow Univ. UK.

26. Sherman, R. A., Hall, M. J. R. and Thomas, S. 2000. Medicinal maggots: an ancient remedy for some contemporary afflictions. Annu Rev Entomol 45, 55-81.
27. Tako, E., Glahn, R. P., Welch, R. M., Lei, X., Yasuda, K. and Miller, D. D. 2008. Dietary inulin affects the expression of intestinal enterocyte iron transporters, receptors and storage protein and alters the microbiota in the pig intestine. Br J Nutr 99, 472-480.

28. Veerman, G., Staelens, S., Broek, H., Plaskie, K., Wesling, F., Roger, L. C., McCartney, A. L. and Assam, P. 2011. Physiological and bifidogenic effects of prebiotic supplements in infant formulae. J Pediatr Gastroenterol Nutr 52, 763-771.

29. Wang, F. R., Ai, H., Chen, X. M. and Lei, C. L. 2007. Hepatoprotective effect of a protein-enriched fraction from the maggots(Musca domestics) against $\mathrm{CCl}_{4}$-induced hepatic damage in rats. Biotechnol Lett 29, 853-858.

30. Wang, Y. W., Field, C. J. and Sim, J. S. 2000. Dietary polyunsaturated fatty acids alter lymphocyte subset proportion and proliferation, serum immunoglobulin G concentration, and immune tissue development in chicks. Poult Sci 79, 1741-1748.

31. Zhang, W. F., Li, D. F., Lu, W. Q. and Yi, G. F. 2003. Effects of isomalto-oligosaccharides on broiler performance and intestinal microflora. Poult Sci 82, 657-663.

\section{초록 : 파리유충 추출물이 랫드의 혈액지질, 면역세포 중량, 맹장 미생물 및 유기산 변화에 미치는 비피더스 활성효과}

박병성 ${ }^{1}$. 박상오 ${ }^{2 *}$

('강원 대학교 동물응용과학부, ${ }^{2}$ 강원대학교 동물자원공동연구소)

인위적 환경에서 사육된 파리유충은 곤충 의생명소재로서 잠재성을 갖는다. 본 연구는 파리유충 에탄올추출물 (EM)을 랫드에게 추출물을 투여하지 않은 대조군과 생체중 $100 \mathrm{~g}$ 당 추출물 $4.0,6.0,8.0 \mathrm{mg}$ 으로 구분하여 40 일 동안 경구투여 하였다. 혈액 중성지방, 총콜레스테롤 및 LDL-C는 대조군과 비교할 때 EM 투여군에서 각각 17.90 , $17.60,16.37 \%$ 낮아졌으나 HDL-C는 $120.48 \%$ 유의하게 증가하였다( $p<0.05)$. 흥선, 비장은 대조군과 비교할 때 $\mathrm{EM}$ 투여군에서 각각 $121.42,121.42 \%$ 농도 의존적으로 증가하였으나 복강지방은 $39.66 \%$ 유의하게 감소하였다 ( $p \times 0.05)$. 혈액 IgG, IgA, IgM 농도는 대조군과 비교할 때 $\mathrm{EM}$ 투여군에서 각각 $135.14,168.65,290.16 \%$ 유의하게 증가하였다( $\beta \times 0.05)$. Bifidobacterium, Lactobacillus는 $\mathrm{EM}$ 투여군이 대조군과 비교할 때 각각 $141.68,135.55 \%$ 증가하 였으나 Bacteroides, Clostridium, Escherichia coli, Streptococcus는 각각 24.96, 46.37, 25.00, and 34.05\% 유의하게 낮아 졌다 $(p \times 0.05)$. 맹장에서 총유기산, 초산과 프로피온산은 $\mathrm{EM}$ 투여군이 대조군과 비교할 때 각각 $131.11,149.34$, $124.88 \%$ 증가하였으나 뷰티르산, 이소뷰티르산, 발레르산, 이소발레르산은 각각 $30.79,72.64,32.90,63.16 \%$ 유의하 게 감소하였다( $p<0.05)$. 본 연구결과는 파리유충 에탄올추출물이 동물의 장 내 미생물 균총 유지 및 유기산 증식을 통한 복강지방, 혈액지질 감소 및 면역세포 발육과 관련한 비피더스 활성효과를 갖는다는 점을 나타낸다. 